\title{
Endemism of Sphinx Moth (Lepidoptera Sphingidae) in the Agroecosystem of Bacusanon, Pangantucan, Bukidnon, Philip- pines
}

\author{
Michelle Senobin-Suelo** \& Alma B. Mohagan² \\ ${ }^{1}$ Central Mindanao University (CMU), Musuan, Bukidnon 8710, Philippines \\ ${ }^{2}$ Faculty of the Biology Department, College of Arts and Sciences, Central Mindanao University, Musuan, Bukidnon 8710, Philip- \\ pines \\ ${ }^{*}$ Corresponding author, email: michelle.suelo5@gmail.com
}

\begin{abstract}
Sphinx moths, or also known as hawkmoths, clearwing moths or hummingbird moths, are nocturnal insects which plays an essential role in the stability of terrestrial ecosystems. There are 117 species of sphinx moth occurring in the Philippines of which 62 species can be found in Mindanao Island. The light trap sampling technique was employed to successfuly collect crepuscular sphinx moths species. This paper aimed to provide information on species composition, endemism, local status and morphological data of sphinx moths in Bacusanon, Pangantucan, Bukidnon. A total of 25 individuals of sphinx moths were documented, which belongs to 9 genera of 13 species namely Acherontia lachesis, Acosmeryx anceus subdentata, Agrius convolvuli, Ambulyx johnsoni, Amplypterus panopus mindanaoensis, Amplypterus panopus panopus, Hippotion boerhaviae, Hippotion rosetta, Marumba ambroinicus luzoni, Psilogramma menephron, Theretra clotho, Theretra nessus and Theretra oldenlandiae. Of the 13 species, the local status revealed that 11 species are common, 1 species rare and 1 species uncommon. Twelve (12) or $92.3 \%$ species are endemic to the Philippines.
\end{abstract}

KEY WORDS Lepidoptera; Mindanao; Moth; Sphinx; Philippines.

Received 15.04.2020; accepted 26.05.2020; published online 30.06.2020

\section{INTRODUCTION}

Sphinx moth is also known as hawkmoths, clearwing moths and hummingbird moth. Hawkmoths plays a crucial role on the stability of terrestrial ecosystems (Primo et al., 2013). They are important nocturnal pollinators (Mohagan et al., 2018; Chiquetto et al., 2018)) in most of the biodiverse regions on the earth and an ideal organism exploring pollinator niches (Johnson et al., 2016). They also served as prey for other higher trophic levels like birds and bats.

With over 160,000 described species (Kawahara \& Breinholt, 2014; Tujuba et al., 2019) of Lepidoptera, they are thought to be the second largest order in class insecta (Tujuba et al., 2019), with most of them being biomass converters and pollinators (Mohagan et al., 2019). Sphinx moth belongs to the family Sphingidae comprising about 1,450 species all over the world (Singh, 2017) and 117 species are occuring in the Philippines, of which 24 are Philippine endemic species and 10 are Philippine endemic subspecies that are widely distributed on the archipelago with some Asian species (Hogenes \& Treadaway, 1998). And like all other insects, sphinx moths have thorax, abdomen and wings which are densely covered with scales. They are distinguished among others because of 
their rapid flying ability, which can reach up to $40 \mathrm{~km} / \mathrm{hr}$ (Akkuzu et al., 2007), bullet-shaped bodies with long, narrow forewings and shorter hindwings and having a long proboscis is the hallmark of this family (Messenger, 1997; Miller, 1997).

As cited in the report of Rafi et al. (2014), like all other organism, most Sphingidae are highly specialized due to the fact that each species live in accordance with the type of their habitat or environmental status like the availability of their suitable host plants as well as environmental factors like altitude, rainfall, sunshine and temperature. Some of the species of hawkmoths are benign in nature and some species possess economic importance.

\section{MATERIAL AND METHODS}

The study was conducted in Barangay Bacusanon, Pangantucan, Bukidnon. The barangay clearance and farm owner permission were secured and approved for light trap sampling. The light trap was set in the agroecosystem facing Mt. Kalatungan. The farm was planted with corn, coffee, rice and bananas but some of the original plants were retained. So it is still a mix forest. The water body is just around $5 \mathrm{~km}$ and the water is clear. It serves as the water source for drinking and bathing for the community. The original trees present are Falcata, Mosese, Dapdap and Tambuyog. The temperature range from $15^{\circ} \mathrm{C}$ to $19^{\circ} \mathrm{C}$ and the weather was foggy with starry night. The light trap (Fig. 1) was used on to collect sphinx moths species. Light traps were set for ten hours from 6 $\mathrm{PM}$ to $4 \mathrm{AM}$ in the morning. We used 500 watts, 12 voltage tungsten bulb powered from portable generator with the source power of 220AC. A $3 \mathrm{~m}$ $\mathrm{x} 3 \mathrm{~m}$ white cloth was established where night flying insects. The samples were collected and photographed. Identification of the collected sphinx moths species was based on morphological structures and using Hogenes \& Treadaway (1998) checklist at Central Mindanao University Museum Zoology Section.

\section{RESULTS AND DISCUSSION}

The light trap sampling at Bacusanon farm yielded abundant moths despite cold temperatures $\left(15^{\circ} \mathrm{C}-19^{\circ} \mathrm{C}\right)$. A total of 25 individuals of sphinx moths which belong to 9 genera and 13 species were documented (see Table 1, Figs. 3-15). The ecological status of sphinx moths based on checklist of Hogenes \& Treadaway (1998) revealed they were all endemic taxa except $A$. panopus panopus mindanaoensis which is widespread in Cebu, Jolo, Leyte, Mindoro, Mindanao, Negros, Panay, Polilio Island, Romblon, Samar, and Sibuyan. The local status of the collected sphinx moths species revealed that all are common species except 1 uncommon species (H. boerhaviae); only A. panopus panopus is rare species.

During sampling period, the temperature was

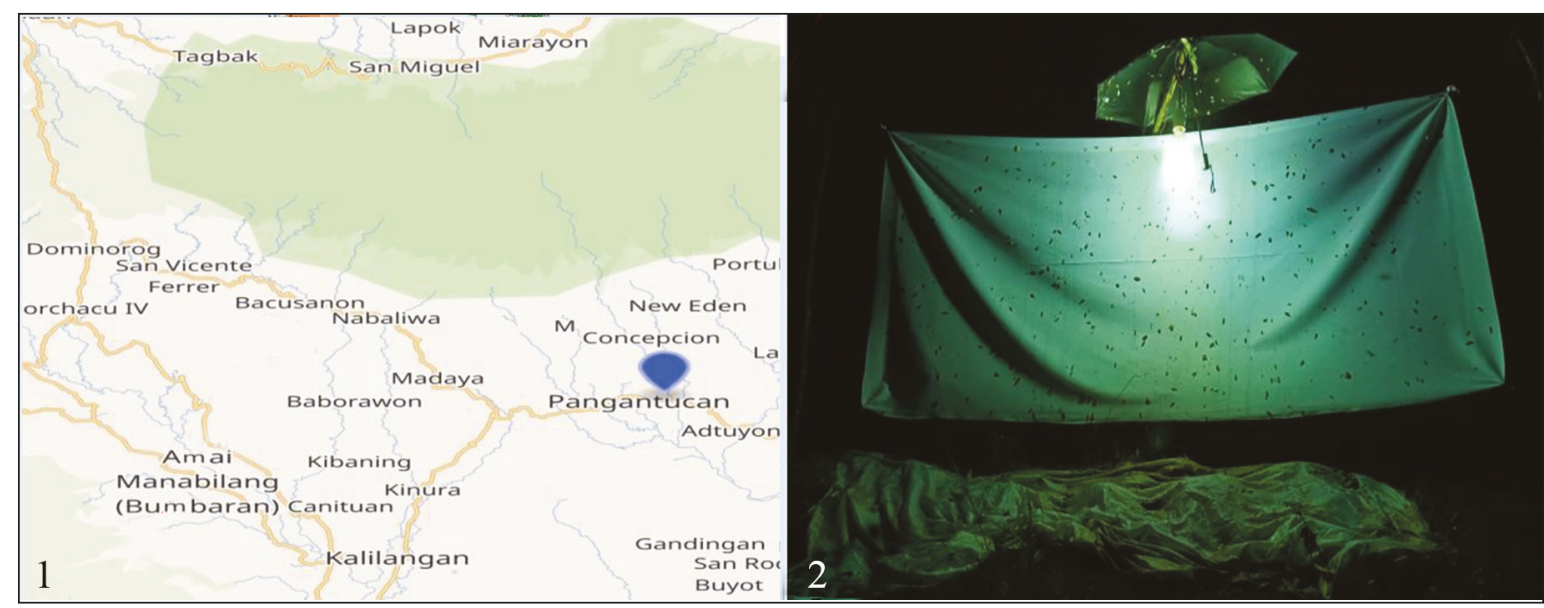

Figure 1. Map of Bacusanon, Pangantucan, Bukidnon. Figure 2. Light Trapping Technique. 
cold and drizzle was observed. Fry \& Waring (1996) stated that light sampling technique is less productive when it is cold and wet. Local conditions such as wind speed, temperature, humidity and the amount of time that the trap is operated are one of the most important factors to consider in collecting sphinx moth species (Jonason et al., 2014). Areas with habitat disturbance as well as human interactions with the environment could also affect the hawkmoth faunal composition (Chiquetto et al., 2018).
Sphinx moths varied in their sizes. Their antennae were proportional to their body sizes ranging from $0.9-2.3 \mathrm{~cm}$, hook ranged from $0.1-0.2$ $\mathrm{cm}$ and eyes ranged from $0.2-0.6 \mathrm{~cm}$. The thorax consists of three segments namely; prothorax ranging $0.3-1.0 \mathrm{~cm}$, mesothorax ranging from $0.2-0.5 \mathrm{~cm}$ and metathorax ranging from $0.2-0.5$ $\mathrm{cm}$. They all vary in color. Forewings ranged from 2.1-7.4 cm while hindwings ranged from 1.2-4.0 $\mathrm{cm}$. Legs measured $1.2-3.8 \mathrm{~cm}$, while eight segments ranged from $1.4-3.7 \mathrm{~cm}$. Spine ranged from

\begin{tabular}{|c|c|c|c|c|c|}
\hline \multicolumn{2}{|l|}{ Species } & $\begin{array}{l}\text { N.of species } \\
\text { collected }\end{array}$ & Endemism & Distribution & $\begin{array}{l}\text { Local } \\
\text { Status }\end{array}$ \\
\hline \multicolumn{2}{|c|}{ Acherontia lachesis (Fabricius, 1798) } & 1 & Endemic & $\begin{array}{l}\text { Bal Ceb, Ley, Luz, Mar, Mdo, } \\
\text { Mno, Neg, Pal, Pan, Pol, Sam }\end{array}$ & Common \\
\hline \multicolumn{2}{|c|}{$\begin{array}{l}\text { Acosmeryx anceus subdentata } \\
\text { (Rothschild \& Jordan, 1903) }\end{array}$} & 1 & Endemic & $\begin{array}{l}\text { Bal, Boh, Cal, Ceb, Din, Jol, } \\
\text { Ley, Luz, Mar, Mdo, Mno, } \\
\text { Neg, Pal, Pan, Sam, Sga, Stu, } \\
\text { Taw }\end{array}$ & Common \\
\hline \multicolumn{2}{|c|}{ Agrius convolvuli (Linnaeus, 1758) } & 1 & Endemic & $\begin{array}{l}\text { Bal, Boh, Cal, Ceb, CmM, Din, } \\
\text { Jol, Ley, Luz, Mdo, Mno, Neg, } \\
\text { Pal, Pan, Sam, Sga Siq }\end{array}$ & Common \\
\hline \multicolumn{2}{|c|}{ Ambulyx johnsoni (Clark, 1917) } & 3 & Endemic & $\begin{array}{l}\text { Ceb, Ley, Luz, Mar, Mdo, } \\
\text { Mno, Neg, Pan, Sam, Siq }\end{array}$ & Common \\
\hline \multicolumn{2}{|c|}{$\begin{array}{c}\text { Amplypterus panopus mindanaoensis } \\
\text { (Inoue, 1996) }\end{array}$} & 3 & & $\begin{array}{l}\text { Ceb, Jol, Ley, Mdo, Mno, Neg, } \\
\text { Pan, Pol, Rom, Sam, Sib }\end{array}$ & Common \\
\hline \multicolumn{2}{|c|}{$\begin{array}{l}\text { Amplypterus panopus panopus } \\
\text { (Cramer. 1779) }\end{array}$} & 2 & Endemic & Bon, Pal & Rare \\
\hline \multicolumn{2}{|c|}{ Hippotion boerhaviae (Fabricius, 1775) } & 3 & Endemic & $\begin{array}{l}\text { Jol, Ley, Luz, Mno, Neg, Pal, } \\
\text { Pan, Sib }\end{array}$ & Uncommon \\
\hline \multicolumn{2}{|c|}{ Hippotion rosetta (Swinhoe, 1892) } & 1 & Endemic & $\begin{array}{l}\text { Bal, Boh, Bon, Ceb, Jol, Ley, } \\
\text { Luz, Mar, Mdo, Mno, Neg, Pal, } \\
\text { Pan, Sga, Siq, Stu, Taw }\end{array}$ & Common \\
\hline \multicolumn{2}{|c|}{ Marumba ambroinicus luzoni (Clark, 1935) } & 5) & Endemic & $\begin{array}{l}\text { Bab, Boh, Ceb, Din, Jol, Ley, } \\
\text { Luz Mar, Mdo, Mno, Neg, Pan, } \\
\text { Sam, Sib, Siq }\end{array}$ & Common \\
\hline \multicolumn{2}{|c|}{ Psilogramma menephron (Cramer, 1780) } & 2 & Endemic & $\begin{array}{l}\text { Bal, Boh, Bon,Ceb, Dum, Jol, } \\
\text { Ley, Luz, Mas, Mdo, Mno, } \\
\text { Neg, Pal, Pan, Sam, Siq, Stu, } \\
\text { Taw }\end{array}$ & Common \\
\hline \multicolumn{2}{|c|}{ Theretra clotho (Drury, 1773) } & 1 & Endemic & $\begin{array}{l}\text { Bal, Boh, Bon, Cal, Ceb, Joy, } \\
\text { Ley, Luz, Mdo, Mno, Neg, Pal, } \\
\text { Pan, Sam, Sib, Siq, Stu, Taw }\end{array}$ & Common \\
\hline \multicolumn{2}{|c|}{ Theretra nessus (Drury, 1773) } & 5 & Endemic & $\begin{array}{l}\text { Bal, Boh, Cal, Cat, Ceb, Din, } \\
\text { Jol, Ley, Luz, Mar, Mas, Mdo, } \\
\text { Mno, Neg, Pal, Pan, Sam, Sib } \\
\text { Siq, Stu }\end{array}$ & Common \\
\hline \multirow[t]{2}{*}{ Theretra oldenlandiae $(\mathrm{F}$} & abricius, 1775) & 1 & Endemic & $\begin{array}{l}\text { Bal, Boh, Ceb Jol, Ley, } \\
\text { Luz, Mdo, Mno, Neg, Pal, Pan, } \\
\text { Pao, Sam, Sib, Siq, Taw }\end{array}$ & Common \\
\hline & $\begin{array}{l}\text { Bab- Babuyanes } \\
\text { Bal- Balabac } \\
\text { Boh- Bohol } \\
\text { Bon- Bongao } \\
\text { Cal- Calamian }\end{array}$ & $\begin{array}{l}\text { Cat- Catanduanes } \\
\text { Ceb- Cebu } \\
\text { CmM- Camiguin } \\
\text { de Luzon } \\
\text { Din- Dinagat }\end{array}$ & $\begin{array}{l}\text { Pao-Panaon } \\
\text { Dum- Dumaran } \\
\text { Ley- Leyte } \\
\text { Luz- Luzon } \\
\text { Mar- Marinduque }\end{array}$ & $\begin{array}{ll}\text { Mas- Masbate } & \text { Pal- Palawan } \\
\text { Mdo- Mondoro } & \text { Pan- Panay } \\
\text { Mno- Mindanao } & \text { Pol- Polilio Island } \\
\text { Neg- Negros } & \text { Rom- Romblon } \\
\text { Pao-Panaon } & \text { Sam- Samar }\end{array}$ & $\begin{array}{l}\text { Sga- Sarangani } \\
\text { Sib- Sibuyan } \\
\text { Siq- Siquijor } \\
\text { Stu- Sibutuc } \\
\text { Jol- Jolo }\end{array}$ \\
\hline
\end{tabular}

Table 1. Species Composition, Endemism, Distribution and Local Status of Sphinx Moths in Bacusanon, Pangantucan, Bukidnon. 

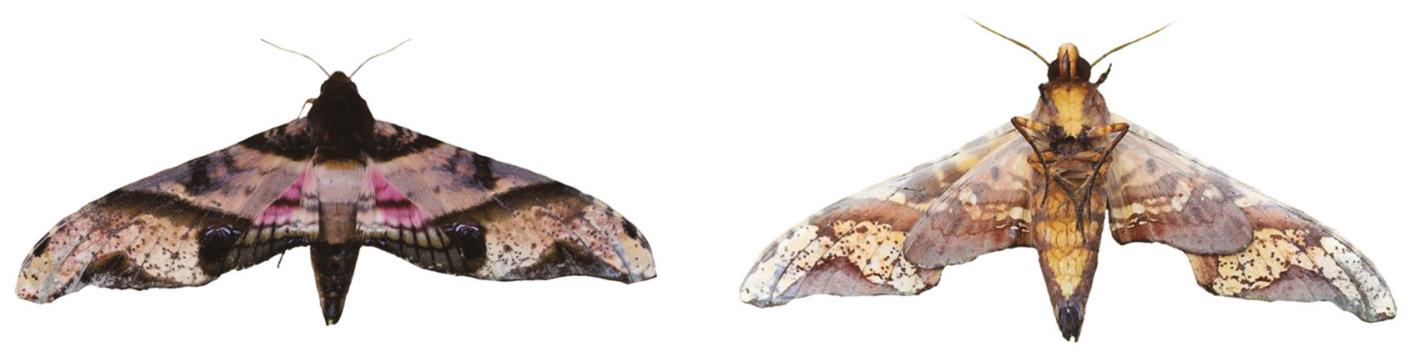

3
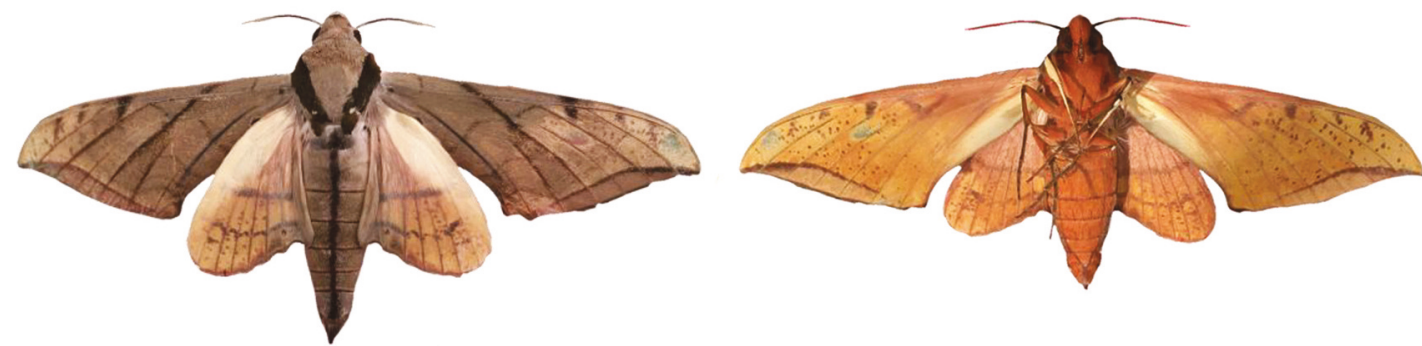

4

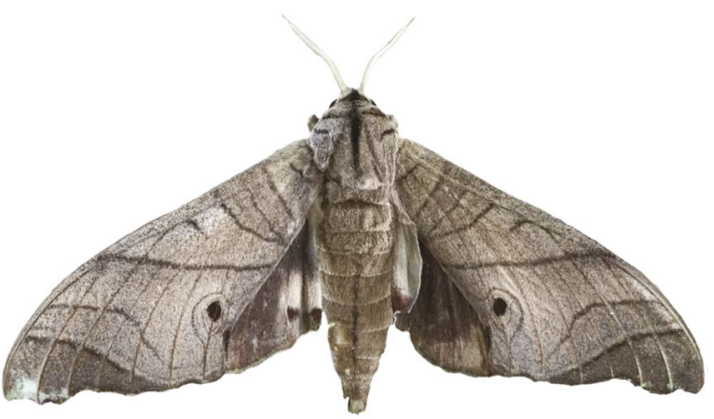

5
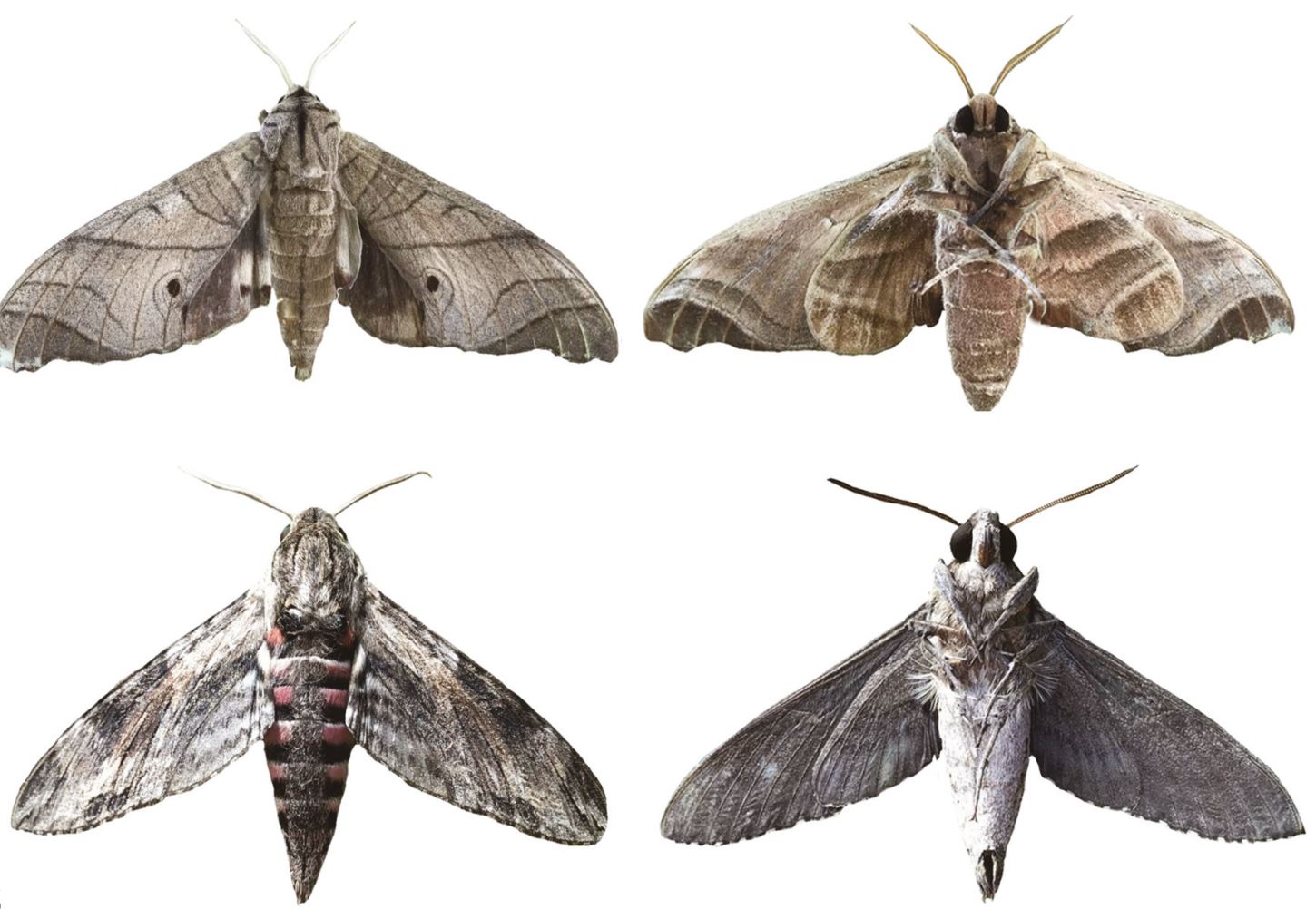

6

Figure 3. Amplypterus panopus mindanaoensis (Inoue, 1996) dorsal and ventral view. Figure 4. Ambulyx johnsoni (Clark, 1917) dorsal and ventral view. Figure 5. Marumba ambroinicus luzoni (Clark, 1935) dorsal and ventral view. Figure 6. Agrius convolvuli (Linnaeus, 1758) dorsal and ventral view. 


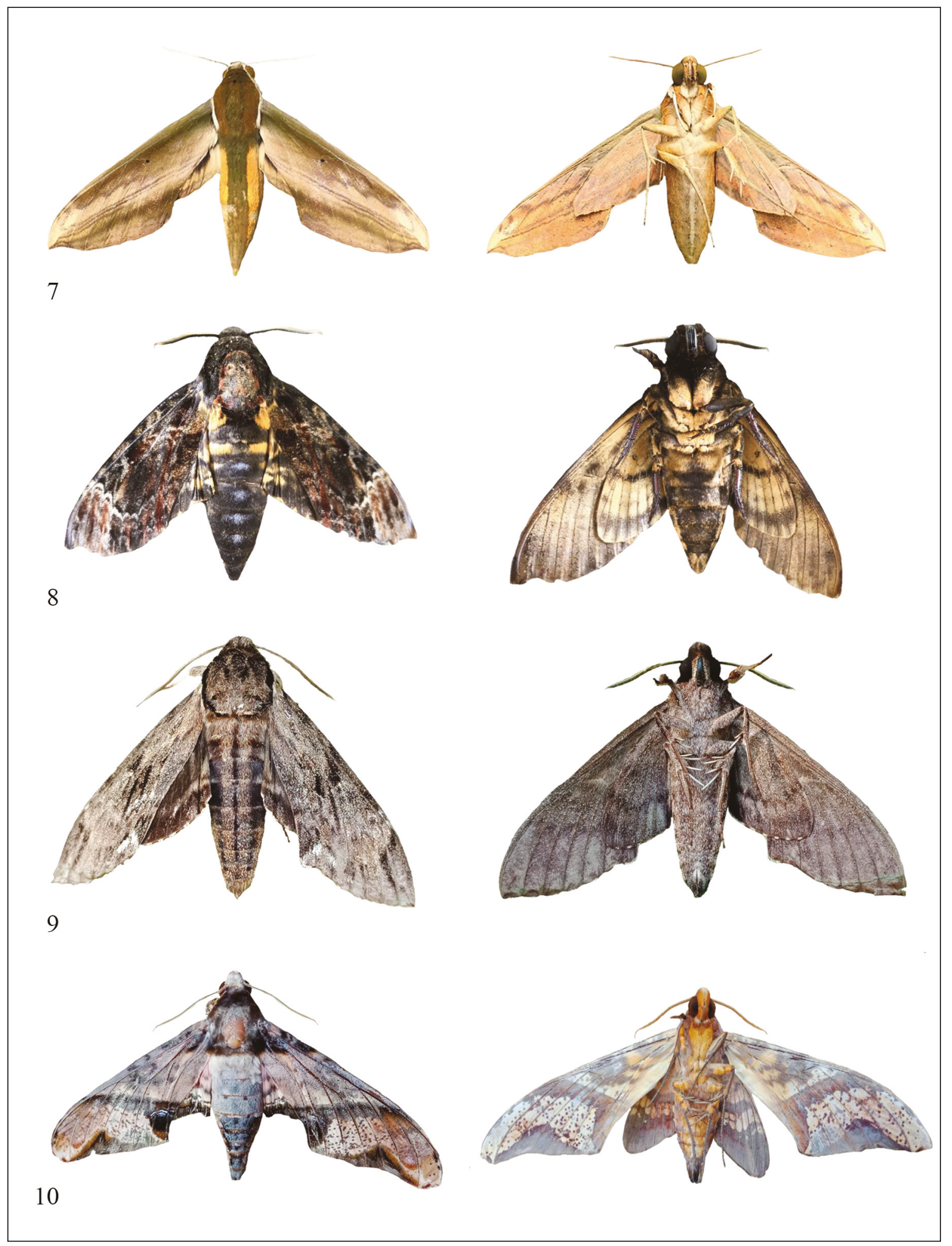

Figure 7. Theretra nessus (Drury, 1773) dorsal and ventral view. Figure 8. Acherontia lachesis (Fabricius, 1798) dorsal and ventral view. Figure 9. Psilogramma menephron (Cramer, 1780) dorsal and ventral view. Figure 10. Amplypterus panopus panopus (Cramer, 1779) dorsal and ventral view. 


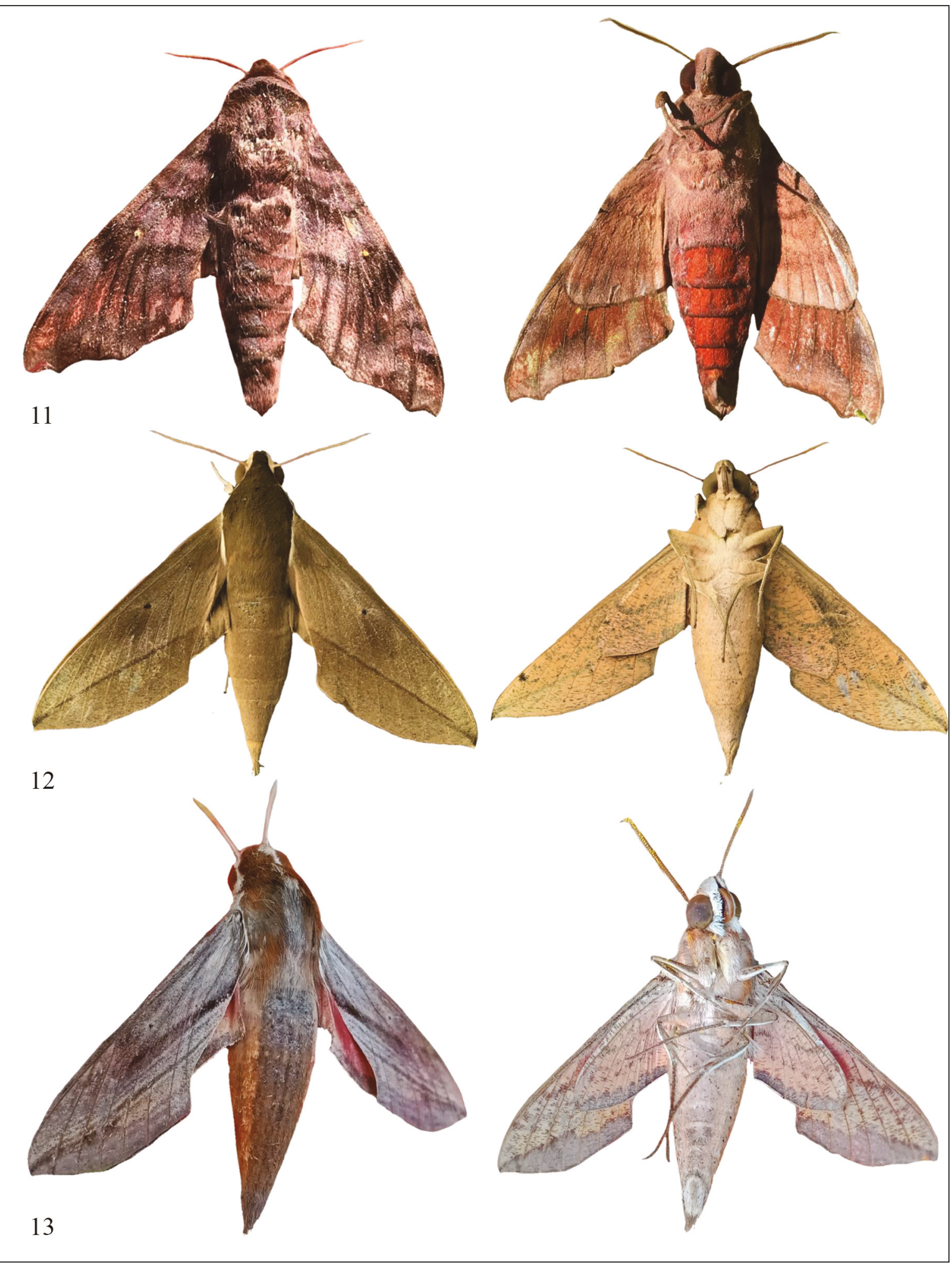

Figure 11. Acosmeryx anceus subdentata (Rothschild \& Jordan, 1903) dorsal and ventral view. Figure 12. Theretra clotho (Drury, 1773) dorsal and ventral view. Figure 13. Hippotion boerhaviae (Fabricius, 1775) dorsal and ventral view. 


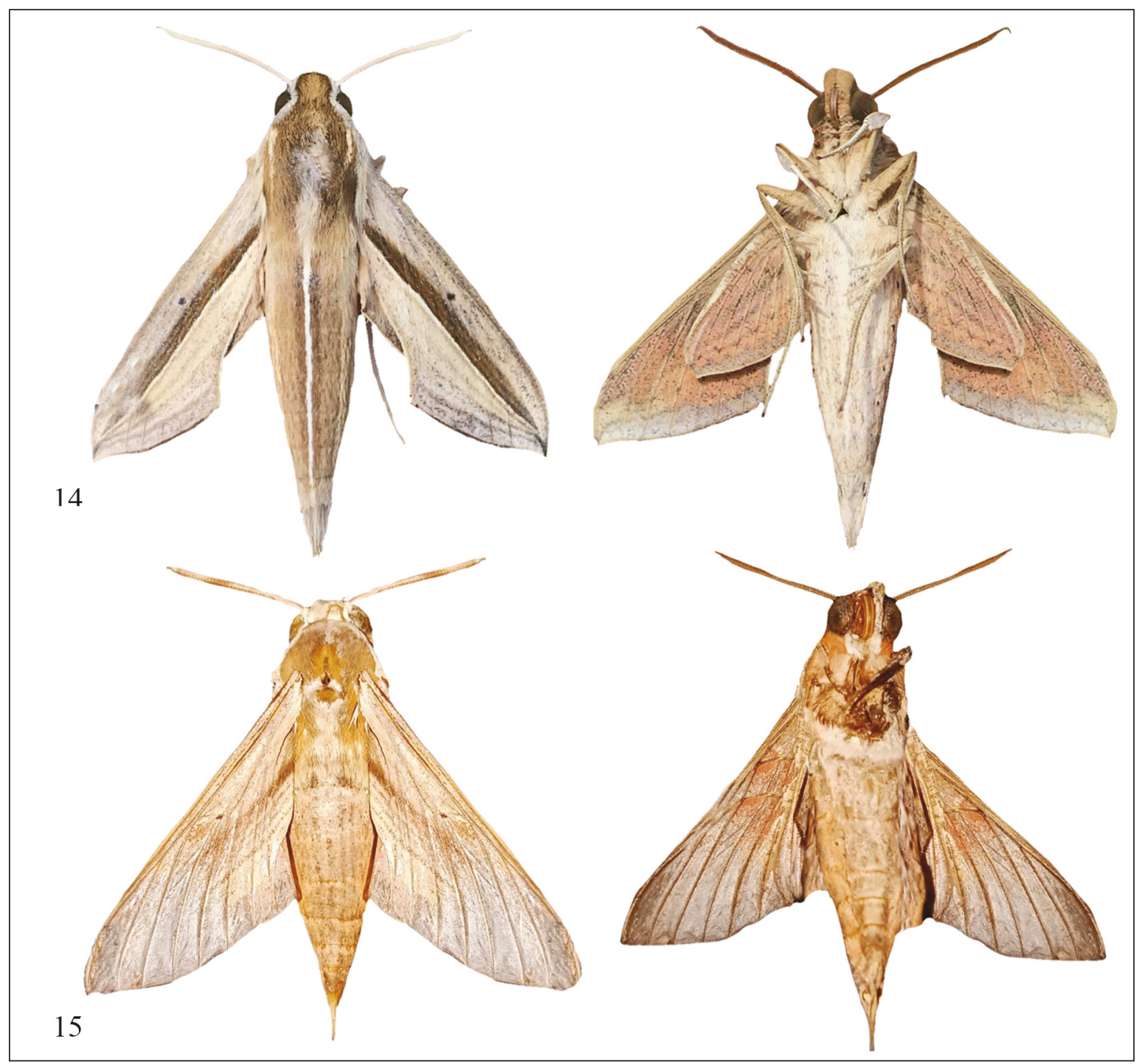

Figure 14. Theretra oldenlandiae (Fabricius, 1775) dorsal and ventral view.

Figure 15. Hippotion rosetta (Swinhoe, 1892) dorsal and ventral view.

$0.1-0.5 \mathrm{~cm}$, while wingspread ranged from 2.6$9.2 \mathrm{~cm}$. It was observed that availability of food and water affects the growth of sphingid moths. Sphinx moths are also fast flyers. Light trapping technique was a very useful method on sampling night flying fauna. They are nocturnal and they are attracted to light. The species of sphingid moths varied on their color and structure. They have narrow forewings and shorter hindwings. Eyespots are present on the forewings and hindwings of some species. Eyespots may resemble eyes and could cause smaller predators to believe them to be the head of larger animal (Stevens, 2005).

\section{CONCLUSIONS}

A total of 12 endemic species (92.3\%) out of 13 recorded species in Bacusanon, Pangantucan, Bukidnon, Philippines were documented, namely: Acherontia lachesis, Acosmeryx anceus subdentata, Agrius convolvuli, Ambulyx johnsoni, Amplypterus panopus mindanaoensis, Amplypterus panopus panopus, Hippotion boerhaviae, Hippotion rosetta, Marumba ambroinicus luzoni, Psilogramma menephron, Theretra clotho, Theretra nessus, and Theretra oldenlandiae. The local status revealed 11 common species and 1 rare species, the $A$. panopus 
panopus. Morphological characteristics are useful in identifying the sphinx moths up to species level.

\section{ACKNOWLEDGEMENTS}

The authors would like to thank Sir Dave Mohagan of Central Mindanao University Museum for facilitating the identification of the species, and the Barangay captain of Bacusanon, Hon. Rodelio Magbanua Lucero and the land owner Mr. Wilferdo Suelo for allowing us conduct our study. The primary author is supported by Department of Science and Technology - Science Education Institute (DOST-SEI STRAND).

\section{REFERENCES}

Akkuzu E., Ayberk H. \& Inac S., 2007. Hawk moths (Lepidoptera: Sphingidae) of Turkey and their zoogeographical distribution. Journal of Environmental Biology, 28: 723-730. http:// www. jeb.co.in/journal_issues/200710_oct07/ paper_05.pdf

Chiquetto-Machado P.I., Amorim F.W. \& Duarte M., 2018. Long-term stability of the hawkmoth fauna (Lepidoptera, Sphingidae) in a protected area of Brazilian Atlantic Rain Forest. Journal of Insect Conservation, 22: 277-286. http://dx.doi.org/10.1007 /s10841-018-0061-0

Fry R. \& Waring P., 1996. A Guide to Moth Traps and their Use. The Amateur Entomologist, 24: 1-60.

Hogenes W. \& Treadaway C.G., 1998. The Sphingidae (Lepidoptera) of the Philippines. Entomologischer Verein Apollo e.v. Frankfurt am main, 17: 17-132. Retrieved from www.zoobodat.at

Johnson S.D., Moré M., Amorim F.W., Haber W.A., Frankie G.W., Stanley D.A. \& Raguso, R. A. 2016. The long and the short of it: a global analysis of hawkmoth pollination niches and interaction networks. Functional Ecology, 31: 101-115. http://dx. doi.org/10.1111/1365-2435.12753

Jonaso, D., Franzen M. \& Ranius T., 2014. Surveying Moths Using Light Traps: Effects of Weather and Time of the Year. PLoS ONE, 9. http://dx.doi.org /0.1371/journal.pone.0092453

Kawahara A.Y. \& Breinholt J.W., 2014. Phylogenomics provides strong evidence for relationships of butterflies and moths. Proceedings of the Royal Soci- ety B, 281. http://dx.doi.org/10.1098/rapb.2014. 0970

Messenger C., 1997. The Sphinx Moths (Lepidoptera: Sphingidae) of Nebraska. Transactions of the Nebraska Academy of Sciences and Affiliated Sciences, 24: 89-141. http://digital commons.un/.edu/tnas/2

Miller W.E., 1997. Diversity and Evolution of Tongue Length in Hawkmoths (Sphingidae). Journal of the Lepidopterists Society, 5: 9-31

Mohagan A.B., Romeo M. Tubongbanua Jr., Daniel O., Amper Aldrin L., Hongco Fulgent P., Coritico Felipe S., Gorme Jr., Victor B. Amoroso., Ruel D., Colong \& Ponce Roy G., 2019. Species Composition, Endemism and Local Status of Hawkmoths (Heterocera: Sphingidae) in the two proposed expansion sites of Mt. Hamiguitan Range Wildlife Sanctuary, Davao Oriental, Philippines. Biological Forum, An International Journal, 11: 236-240.

Mohagan D.L., Solis E., Felipe Gorme Ruel M., Colong Socorro H., Laraga Glenda Z., Doblas,Kathleen Grace S., Paraguas Dave P. Mohagan., Alma B. Mohagan. \& Bergquist Tomas, 2018. Hawkmoths (Heterocera: Sphingidae) diversity and Status on selected vegetation types of a protected natural forest (Mt. Hamiguitan Wildlife Sanctuary, San Isidro, Davao Oriental) and Ecotourist Area (Busay Garden Marilog District, Davao City) Philippines. International Journal of Current Research in Life Sciences, 7: 2684-2690.

Rafi M.A., Sultan A., Kitching I.J., Pittaway A.R., Markhasiov M., Khan M.R. \& Naz F., 2014. The Hawkmoth Fauna of Pakistan (Lepidoptera: Sphingidae). Zootaxa, 3794: 393-418. http://dx.doi.org/ 10.11646/zootaxa.3794.3.4

Primo L.M., Duarte J.A. \& Machado I.C., 2013. Hawkmoth fauna (Sphingidae, Lepidoptera) in a semi-deciduous rain forest remnant: composition temporal fluctuations, and new records for northeastern Brazil. Annals of the Brazilian Academy of Sciences, 85: 1177-1188. www.scielo.br/aabc

Singh D., 2017. DNA barcoding of Some Indian species of hawkmoths based on COI gene (Lepidoptera:Sphingidae). Journal of Entomology and Zoology Studies, 5: 35-40.

Stevens M., 2005. The role of eyespots as anti-predator mechanisms, principally demonstrated in the Lepidoptera. Biological reviews 80: 1-16. http://dx.doi. org/10.1017/S1464793105006810

Tujuba T. F., Sciarretta A., Hausmann A. \& Abate G. A., 2019. Lepidopteran biodiversity of Ethiopia: current knowledge and future perspectives. ZooKeys, 882: 87-125. http://dx.doi.org/10.3897/zookeys.882.36634 